\title{
Gas-forming gluteal abscess after intramuscular self- injections due to Clostridium perfringens
}

\author{
Rafael Garcia-Carretero, ${ }^{1}$ Marta Gonzalez-Moreno, ${ }^{2}$ Belen Rodriguez-Maya, ${ }^{2}$ \\ Elena Isaba-Ares ${ }^{2}$
}

${ }^{1}$ Internal Medicine, Hospital Universitario de Mostoles, Mostoles, Spain ${ }^{2}$ Department of Internal Medicine, Hospital Universitario de Mostoles, Mostoles, Spain

\section{Correspondence to}

Dr Rafael Garcia-Carretero, rgcarretero@salud.madrid.org

Accepted 22 January 2019

\section{DESCRIPTION}

A 59-year-old woman with a medical history of personality disorder (cluster B disorders: borderline and histrionic) and drug misuse was admitted to our hospital with increasing pain in the left buttock and thigh for the last 3 weeks. She was presenting a body temperature of $38.5^{\circ} \mathrm{C}$. She reported self-injected doses of metamizole $(2 \mathrm{mg}$ two times per day), although this information was confirmed several days after admission.

On physical examination, she presented with a large, tender, fluctuant lump on the left buttock and upper half of the left thigh. The overlying skin was warm and red. Laboratory tests showed a white cell count of 16300 leucocytes $/ \mathrm{mm}^{3}$ (82\% neutrophils and $10 \%$ bands), haemoglobin of $113 \mathrm{~g} / \mathrm{L}$ and platelet count of $401 \times 10^{9} / \mathrm{L}$. C reactive protein was $194 \mathrm{mg} / \mathrm{dL}$ (normal level: <5 mg/dL). Kidney, liver, lipids and urine panels were normal. Blood cultures were negatives.

A CT scan confirmed a huge multilobulated abscess in the left buttock (measuring $15 \times 11 \times 8 \mathrm{~cm}$ ), involving the left gluteal muscles, and containing gas bubbles (figure 1). The abscess had spread into the adjacent tissue and the left iliac crest.

We decided to initiate meropenem $1 \mathrm{~g}$ every 8 hours and linezolid $600 \mathrm{mg}$ two times per day. She was then referred to the Department of Trauma and Orthopaedic Surgery, where she underwent drainage and surgical debridement of the infected, necrotic tissue. Muscle tissue samples revealed pure growth of Clostridium perfringens, sensitive to metronidazole, amoxicillin-clavulanate, piperacillin-tazobactam and meropenem. The patient was on meropenem for 4 weeks and on amoxicillin-clavulanate for 1 week. She improved rapidly,

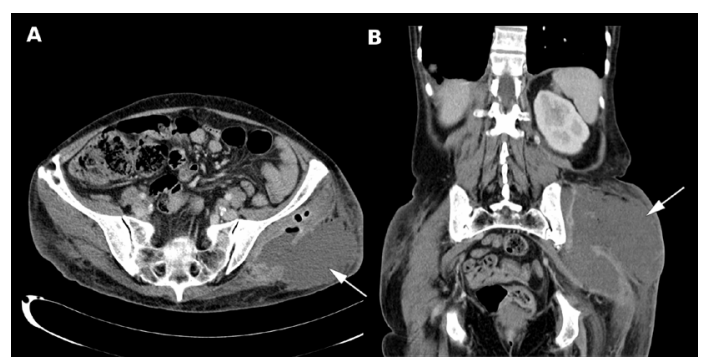

Figure 1 Abdominal CT scan showing how the abscess had replaced the three gluteal muscles and spread into the panniculus adiposus of the left buttock (slide A: transverse plane; slide B: coronal plane). Arrows are indicating the large abscess. Slide $A$ also shows air bubbles inside the abscess. fever disappeared and $\mathrm{C}$ reactive protein was back in the normal range in the following 5 days. In a follow-up, 2 months after discharge, the patient was well, with no pain or functional impairment. A repeat CT scan was then performed, which showed a residual lesion measuring $1 \times 0.8 \times 0.8 \mathrm{~cm}$.

Necrotising soft-tissue infections are rare, but severe, infections associated with high morbidity and mortality. ${ }^{1}$ Treatment should be aggressive, both surgical and antibiotic, and the outcome depends on the location, micro-organisms involved and patients' prognostic factors, such as diabetes, immunosuppression, drug abuse and age. The microbiological profile is primarily polymicrobial, with both Gram-negative and Gram-positive bacteria. Streptococcus and Staphylococcus are the most commonly isolated bacteria in monomicrobial infections. $^{2}$

Clostridium is a Gram-positive, anaerobic micro-organism, which is usually saprophytic, that can cause several syndromes, including soft-tissue infections. ${ }^{3}$ Several cases have been reported on severe C. perfringens infections and gas-forming abscesses, highlighting the mortality and the difficulty in establishing a diagnosis in the early stages. ${ }^{4}$

C. perfringens can release histotoxins (alpha, beta, epsilon and iota), some of which are able to cause gas gangrene and widespread necrotising soft-tissue infection. ${ }^{5}$ In our patient, gas inside the abscess led us to consider that an anaerobic micro-organism was responsible for the infection.

The patient was self-injecting doses of metamizole. Although she admitted this, she gave us no valid reason for doing so. It is worth noting that some studies have established a relationship between factitious disorder (Munchausen syndrome) and borderline disorder (cluster B personality disorder). ${ }^{6}$

\section{Learning points}

- Necrotising soft-tissue infections after intramuscular injections are not frequent, but may be associated with high morbidity and mortality.

- Clostridium perfringens infections are not frequent micro-organisms causing necrotising soft-tissue infections, but gas-forming abscesses may lead us to suspect clostridial infections.

- When suspected, early implementation of broad-spectrum antibiotic therapy, and surgical drainage and debridement are the key to manage this kind of abscess. 
Contributors RGC wrote the first draft. MG-M and BR-M revised the draft. EI-A edited the CT slides.

Funding The authors have not declared a specific grant for this research from any funding agency in the public, commercial or not-for-profit sectors.

Competing interests None declared.

Patient consent for publication Obtained.

Provenance and peer review Not commissioned; externally peer reviewed.

\section{REFERENCES}

1 Friederichs J, Torka S, Militz M, et al. Necrotizing soft tissue infections after injection therapy: higher mortality and worse outcome compared to other entry mechanisms. J Infect 2015;71:312-6.
2 Stevens DL, Bisno AL, Chambers HF, et al. Practice guidelines for the diagnosis and management of skin and soft tissue infections: 2014 update by the infectious diseases society of America. Clin Infect Dis 2014;59:147-59.

3 Yang CC, Hsu PC, Chang HJ, et al. Clinical significance and outcomes of Clostridium perfringens bacteremia-a 10-year experience at a tertiary care hospital. Int I Infect Dis 2013;17:e955-60.

4 van Bunderen CC, Bomers MK, Wesdorp E, et al. Clostridium perfringens septicaemia with massive intravascular haemolysis: a case report and review of the literature. Neth $J$ Med 2010;68:343-6.

5 Shindo Y, Dobashi Y, Sakai T, et al. Epidemiological and pathobiological profiles of Clostridium perfringens infections: review of consecutive series of 33 cases over a 13year period. Int J Clin Exp Pathol 2015;8:569-77.

6 Gordon DK, Sansone RA. A relationship between factitious disorder and borderline personality disorder. Innov Clin Neurosci 2013;10:11-13.

Copyright 2019 BMJ Publishing Group. All rights reserved. For permission to reuse any of this content visit https://www.bmi.com/company/products-services/rights-and-licensing/permissions/

BMJ Case Report Fellows may re-use this article for personal use and teaching without any further permission.

Become a Fellow of BMJ Case Reports today and you can:

- Submit as many cases as you like

- Enjoy fast sympathetic peer review and rapid publication of accepted articles

- Access all the published articles

Re-use any of the published material for personal use and teaching without further permission

For information on Institutional Fellowships contact consortiasales@bmjgroup.com

Visit casereports.bmj.com for more articles like this and to become a Fellow 